\title{
INFLUENCE OF MINIFLAPS ON SAILPLANE FLIGHT CHARACTERISTICS
}

\author{
Peep LAUK ${ }^{1}$, Karl-Eerik UNT ${ }^{2}$ \\ ${ }^{1}$ Faculty of Mechanical Engineering, Tallinn University of Technology, Ehitajate tee 5, \\ 19086 Tallinn, Estonia \\ ${ }^{1,2}$ Department of Aircraft Engineering, Estonian Aviation Academy, Lennu 40, Reola, \\ Ülenurme, Tartu County, 61707, Estonia

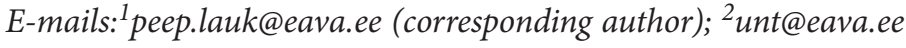

Received 25 June 2014; accepted 17 September 2014

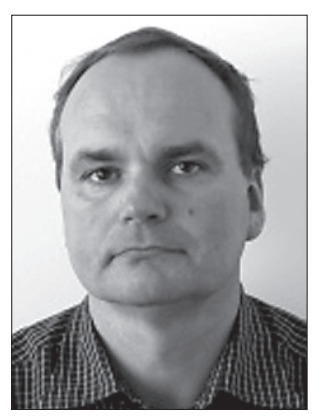

Peep LAUK, $M S c$

Date and place of birth: 1966, Elva, Estonia.

Education: since 2014, Tallinn University of Technology, PhD student; since 1989, Estonian University of Life Sciences.

Affiliations and functions: lecturer of Estonian Aviation Academy (Aircraft Aerodynamics and Structure).

Research interests: sailplane and UAV aerodynamics.

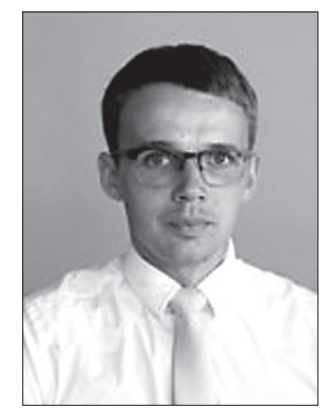

\section{Karl-Eerik UNT, $M S c$}

Date and place of birth: 1983, Tartu, Estonia.

Education: since 2006, Estonian Aviation Academy; since 2010, Tallinn University of Technology.

Affiliations and functions: Estonian Aviation Academy, MTO training manager.

Research interests: composite repairs, fasteners, aviation legislation, polymer- and composite materials and aircraft construction materials.

Abstract. The effect of miniflaps for increasing the L/D ratio and the lift coefficient has been studied on airliners as well as on UAV-s and wind turbines. For sailplanes the lift when $\mathrm{Cl}>1.0$ is of main interest. As the maximum wing loading of racing sailplanes reaches $60-62 \mathrm{~kg} / \mathrm{m}^{2}$, it is necessary to achieve a high $\mathrm{Cl}$ max $(1.7-1.8)$ in thermals. In this case the decrease in TAS caused by a high $\mathrm{Cl}$ max even compensates for the drop of the L/D ratio to a certain extent, as the climb speed will increase when the spiral flight radius diminishes in thermals. To bring the $\mathrm{L} / \mathrm{D}$ to $\mathrm{Cl}>1.0$, a $2 \%$ chord miniflap at a $30^{\circ}$ deflection angle was attached to the trailing edge of a Jantar-Standard 3 type sailplane wing (airfoil NN-8). In flight tests it was found that the miniflap increased the sailplane's $\mathrm{Cl}$ max to $1.35-1.66$, i.e. by $23 \%$ (Re $1.0-0.92 \times 10^{6}$ ). At the same time the $\mathrm{L} / \mathrm{D}$ ratio $\mathrm{Cl}$ increased by over 1.0. Especially good $\mathrm{L} / \mathrm{D}$ improvement was noted with $\mathrm{Cl}$ at 1.13-1.19. In thermal $\mathrm{Cl}$ of $1.57-1.65$ the roll control was good. At lower $\mathrm{Cl}<1.0$ values, the miniflap reduced the $\mathrm{L} / \mathrm{D}$ ratio in comparison with a normal configuration.

Keywords: miniflap, airfoil, sailplane, L/D ratio.

\section{Introduction}

A miniflap (also a microflap, a mini TED a. o.) is a $0.5-4 \%$ chord length flap of the trailing edge, meant for increasing the lift coefficient and decreasing the profile drag at higher lift coefficients. Miniflaps may be divided into three classes: a mini plain flap, a mini split flap and a Gurney flap (Gf). The latter is at a $90^{\circ \circ}$ angle with the airflow. The auxiliary device which increases the lift coefficient, first used by the car racer Dan Gurney, was acknowledged in aviation after the publication of 
(Liebeck 1978). Thus, when a 1.25\% high Gurney flap was used, the maximum lift coefficient of the Newman airfoil increased, but, surprisingly, the drag coefficient diminished at the same time. Still, at a Gf height of over $2 \%$, the lift coefficient increased, and the drag began to increase faster.

In his search for the solution of the paradox that arose, Liebeck created a hypothesis according to which the vortices behind the Gf are accompanied by the diminishing of the thickness of the trailing edge boundary layer, thus decreasing the growth of the drag at an increasing lift force (Fig. 1). This hypothesis was confirmed by tests which showed that the NACA 4412 airfoil's boundary layer transition separation location lengthened from 92 to 98\% when adding a $1 \%$ Gf, and an AoA of $4^{\circ \circ}$ (Jang et al. 1998). At the same time a $\mathrm{Cl}$ of 0.818 increased to 1.167 (Fig. 2).

In spite of its small size, the miniflap is a surprisingly effective means for increasing the lift force. Using the same airfoil, it was found that a $4 \%$ high Gf increased the lift force more than a $25 \%$ chord length plain flap deflection of $+9^{\circ \circ}$ (Vlasov et al. 2007). At the same time, the hinge moments caused by the deflected flaps are smaller. At lower miniflap deflection angles, the profile drag diminishes significantly (Bloy, Durrant 1995).



Fig. 1. Airflow downwash at the wing profile's trailing edge generated by the Gurney flap (Liebeck 1978)

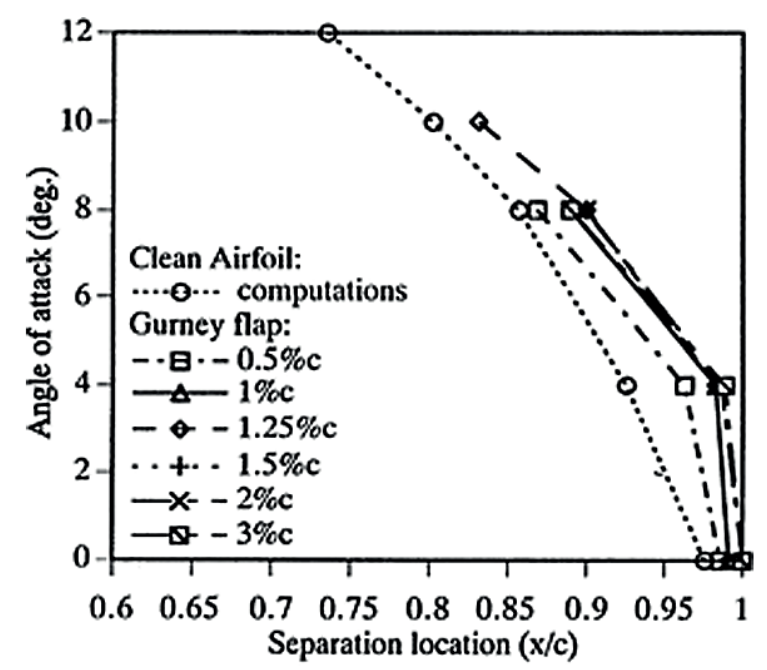

Fig. 2. The effect of the Gurney flap size on the upper surface's boundary layer separation location (Jang et al. 1998)
The airfoil NACA 63 2-215 L/D max was retained at $2 \% \mathrm{C}$ when a $45^{\circ}$ miniflap was used at a higher lift coefficient, $\mathrm{Cl}$. When the flap slope angle was increased to $90^{\circ}$, the lift force increased but the L/D max decreased. When the miniflap deflection angle is increased by more than $45^{\circ}$, the lift coefficient growth intensity will diminish (Fig. 3).

Thus, with a symmetric airfoil, NACA 0012, the $\mathrm{Cl}$ max increased $12.3 \%$ at a deflection angle of $45^{\circ}$ of a $1.5 \%$ chord length miniflap, $15.1 \%$ at $60^{\circ}$ and $17.4 \%$ at $90^{\circ}$ (Wang et al. 2008).

The use of a miniflap increases the wing pitching moment, depending on the miniflap's width and deflection angle.

When using airfoil NACA 5414, Cl 1.0 increased at the miniflap of $2 \% \mathrm{C}$ and fixed angle of $45^{\circ}$ from $\mathrm{Cm}=$ -0.122 to 0.225 (Fig. 4) (Bloy et al. 1997).

Similarly to the use of the plain flap, the tilt of the miniflap increases the reach of the HQ-17 airfoil's surface part to some extent, as the angle of attack is smaller at the same $\mathrm{Cl}$ (Bechert et al. 2001). This diminishes the role of the vortices behind the miniflap for the whole drag (Fig. 5). Behind the miniflap, depending on the chord length and angle of attack, there is a similar von Karman vortex street (van Damm et al. 2007).

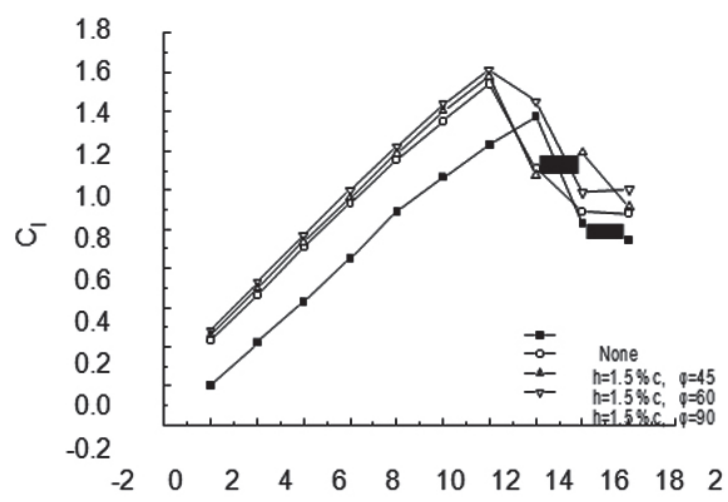

Fig. 3. The influence of a $1.5 \%$ chord length miniflap with a different deflection angle on the NACA $0012 \mathrm{Cl}$ max (Wang et al. 2008)

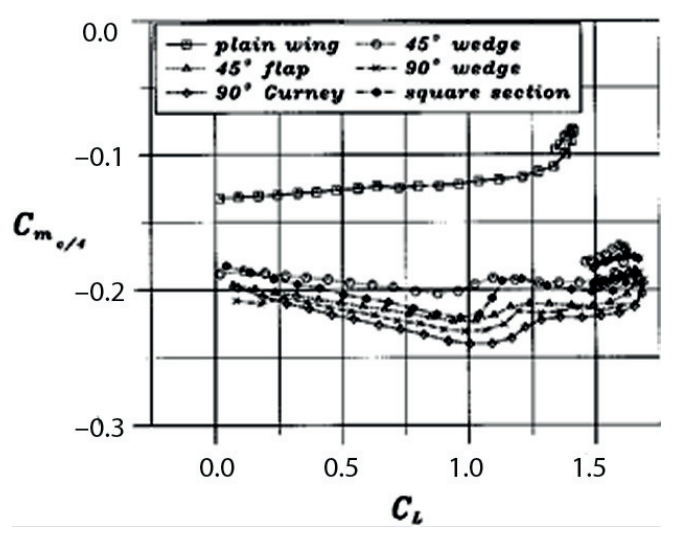

Fig. 4. Variation of pitching moment coefficient about quarterchord line with lift coefficient (Bloy et al. 1997) 


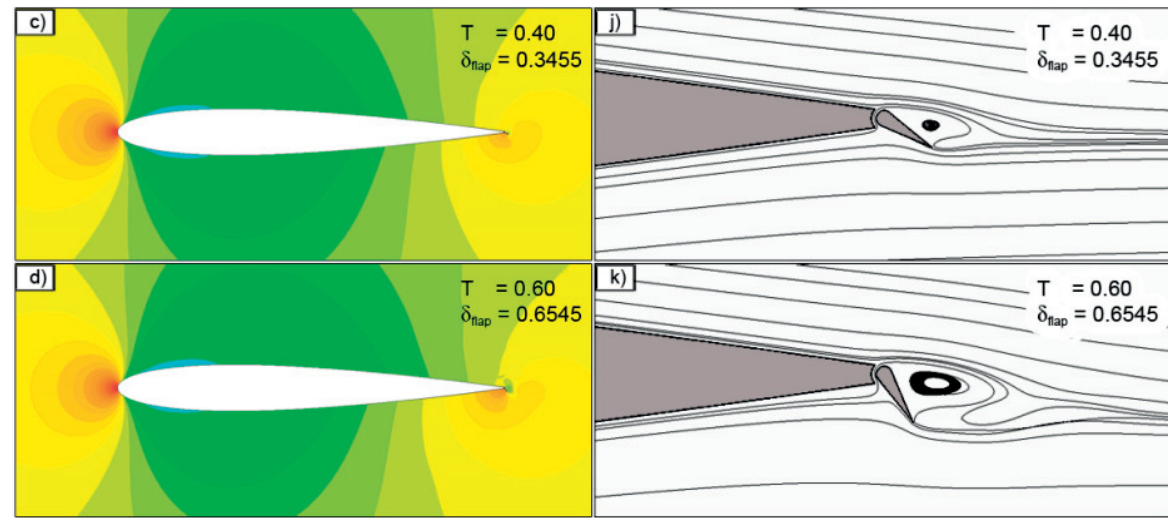

Fig. 5. The influence of the miniflap deflection angle on NACA 0012 airfoil's pressure distribution and trailing edge vortices (van Damm et al. 2007)

\section{Review}

In commercial aviation, the miniflap deflection in flight at subsonic speeds, $0.70-0.82 \mathrm{M}$, enables to decrease the wing drag from CL 0.53 (Richter 2010). The mini split flap is considered to be the most effective type. Various studies have pointed out that, depending on the aeroplane's type, the optimum flap deflection angle is 7.5$22.5^{\circ}$ (Gardner et al. 2006). A certain role in the weakening of the drag might also be attributed to a decrease of $2-2.5^{\circ}$ of the body slope angle. In wind tunnel tests using the Airbus A340-300 model with a Ma of 0.82, the use of a $2 \%$ chord mini split flap at a $7.5^{\circ}$ deflection angle increased the aircraft's $\mathrm{L} / \mathrm{D}$ value by $4.4 \%$ at a $\mathrm{Cl}$ of 0.65 and by $6.07 \%$ at a $\mathrm{Cl}$ of 0.67 (Fig. 6). This corresponds
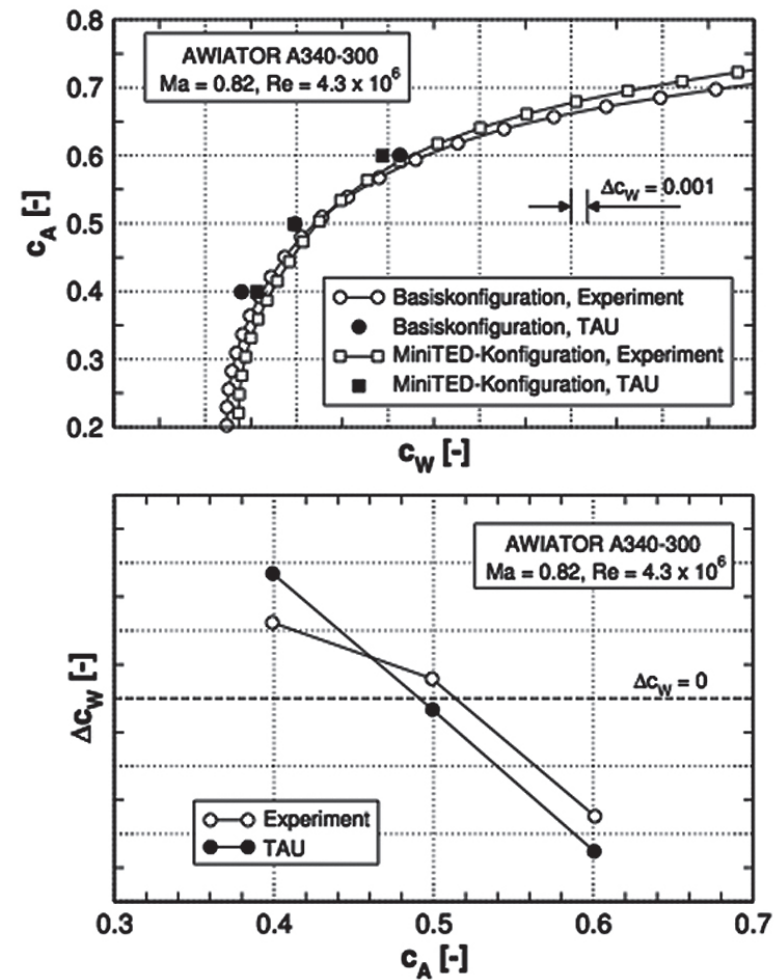

Fig. 6. The influence of a mini split flap $\left(7.5^{\circ}\right)$ on an A340-300 drag at various $\mathrm{Cl}$ values (Richter 2010) to an A340-300 flight weight of respectively $181 \mathrm{MT}$ and 224.7 MT at flight level (FL) 390 and with Ma of 0.82. The fuel consumption decreases in the same way. The obtained results are close to the effect of using winglets. It should be pointed out that the use of miniflaps for airliners gives significant results at wing loadings over $600-700 \mathrm{~kg} / \mathrm{m}^{2}$. The highest fuel economy is achieved with the parallel usage of miniflaps and winglets. If there is need, by changing the angle of the miniflaps during the flight, the load distribution can be changed as well (Gardner et al. 2006), thus decreasing the wing bending moment and the effect of turbulence. A similar effect was achieved when the Trailing Edge Wedge was used for the airfoil S 904 (Bruscoli 2011). At Re $1 \times 10^{6}$, with a $2 \%$ chord length and $0.8 \%$ height $\mathrm{T}$. E. Wedge and a $\mathrm{Cl}$ of 0.52 , the drag coefficient dropped from 0.0083 to 0.0049 and with a $\mathrm{Cl}$ of 0.8 , from 0.0103 to 0.0068 (Fig. 7). Unlike with other kinds of miniflaps, when the T. E. Wedge was used, the $\mathrm{Cl}$ max decreased when compared to the standard profile.

The above mentioned airfoil with a TE Wedge could be used for UAV-s, solar powered aircraft and sailplanes.

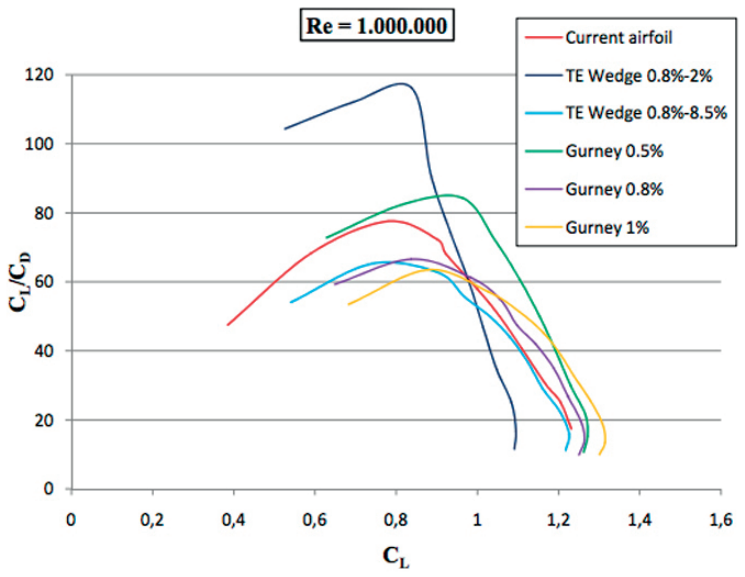

Fig. 7. The influence of various types of miniflaps on the S 904 airfoil's L/D value (Bruscoli 2011) 
In the Boeing CLEEN programme (Wilsey 2012), miniflaps were tested on an American Airlines' Boeing 737-800 in September 2012. 3\% chord-length mini plain flaps at a $30^{\circ}$ angle were used. In addition to reducing the fuel consumption, the miniflaps enabled to reduce noise both at takeoff and at landing, as the necessary airspeed at takeoff is lower and the plane's angle of ascent is greater.


Fig. 8. The influence of the lift coefficient, circling radius and bank angles on the climb performance of the Diana 2 glider a) wide thermal (B), b) middle thermal (C) (Kubrynsky 2006)

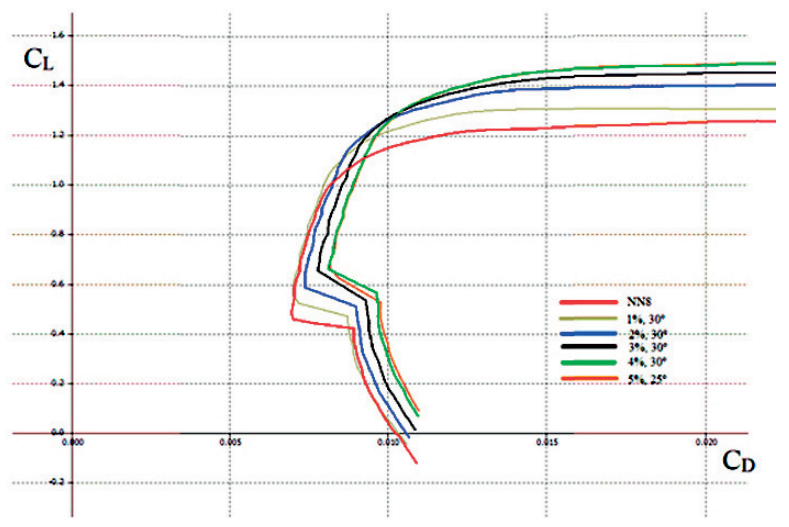

Fig. 9. Influence of various miniflaps on a similar airfoil (NN8) aerodynamic characteristics based on XFLR $5\left(\operatorname{Re} 1.1 \times 10^{6}\right)$ (Balagura 2013)
On gliders, miniflaps are of interest in the thermal regime, when CL > 1.0. A higher wing load 50-60 kg/ $\mathrm{m}^{2}$ used for $15 \mathrm{~m}$ and $18 \mathrm{~m}$ class sailplanes presupposes an advisable flap lift coefficient $\mathrm{Cl}$ of $1.4-1.6$ in thermals (Fig. 8). With an increase of the lift coefficient to 1.3-1.5, the Diana 2 sailplane's climbing speed increased by 0.2 $\mathrm{m} / \mathrm{s}$ in medium wide thermals and by $0.4 \mathrm{~m} / \mathrm{s}$ in narrow thermals (Kubrynsky 2006). The flap positions of $+14^{\circ}-$ $+28^{\circ}$ that were used enabled to raise the CL max to $1.65-$ 1.7 , but from a CL of 1.4-1.45 the profile drag starts to increase rather sharply as the boundary layer starts to separate from the flap's surface and also from a CL of 1.5 the roll control starts to degrade.

To investigate the influence of miniflaps on gliders, test flights with a DG-1000 were made on Prof. Joseph Mertens' (Akademische... 2005-2006) initiative in Aachen in 2006. For this purpose, $20 \mathrm{~mm}$ miniflaps (2.2\%) C were used. 5 test flights were made at flap deflection angles $+15^{\circ},+30^{\circ},+45^{\circ},+60^{\circ}$ and $+90^{\circ}$. In ther$\mathrm{mal}$, the best results were achieved at flap deflection at $+30^{\circ}$ and $+45^{\circ}$. Due to greater drag at landing, the most favourable flap deflection was $+90^{\circ}$. It appeared that at flap deflection of $+60^{\circ}$ and $+90^{\circ}$ the drag increased significantly, but no significant lift increase was added. Unfortunately, due to bad weather conditions, it was not possible to continue with the tests.

As the wing load and aspect ratio of new sailplane models are increasing, the need to use a CL of $1.5-1.7$ is increasing as well.

To model the miniflap, the XFoil programme (Drela 1989) XFLR5 v. 696 was used. With the wing section


Fig. 10. A fixed miniflap on the sailplane Jantar-Standard 3 (photo by Karl-Erik Unt) 
SZD-48-3 Jantar-Standard, 3 similar NN8 airfoils were used on the sailplane, of which the most optimum variant was a $2 \%$ c length miniflap at a $30^{\circ}$ angle. With the miniflap airfoil NN-8 the drag was lower than CL > 1.02 in the standard variant, also the Cl-max increased (Fig. 9).

To test the theoretical results, miniflap sections at a fixed angle from $1.5 \mathrm{~mm}$ thick CFRP with a relative wing chord ratio of $2 \%$ incl. ailerons were made at the Department of Aircraft Engineering of the Estonian Aviation Academy. The miniflaps were fixed with a double-sided adhesive tape (Fig. 10).

\section{Methodology}

In flight tests, the methodology developed by Johnson was used (Johnson 1989). In addition to comparing the sink speed, the parallel flight method was applied (Hendrix 2011). Before the flight tests, the altimeter and speed indicator were calibrated; the test equipment that was used was the air data test set D. Marchiori MPS 43. Also, the air tightness of the pipes of the gages was checked and additional gages were installed. To calibrate the airspeed indicator in flight, the static probe DFS-60 was used. The measurements were made at an IAS of 21-28 m/s.

A table of calibrated speeds was compiled on the basis of the results collected (Fig. 11). The Dynon Avionics equipment D100 was used for measuring and recording, and a Pitot tube was attached to the sailplane for recording the flight parameters. To record the data from mechanical gages and to observe the airflow by tuft, GoPro cameras were used, one camera was attached to the stabilizer and two in the cockpit. In test flights, the parallel flight method with sailplanes of the same type was applied. A miniflap was used for one sailplane, another was used for comparison. Before the test flights the sailplanes were weighed together with pilots and, according to necessity, water ballast was added. Both sailplanes had the same centre of gravity and wing loading (G/S $\left.35.78 \mathrm{~kg} / \mathrm{m}^{2}\right)$.

In the early morning, the sailplanes were towed by planes simultaneously to $1,700 \mathrm{~m}$ from the ground. During the following glide, the sailplanes flew parallel to each other at a distance of 30-50 m at equal speeds. To find out and compare the sink speed, the flight was divided into separate parts. The same speed was retained for 240 seconds and, at the same time, the sink speed was measured. The measurements were stopped at the height of ca $600 \mathrm{~m}$ which was higher than the inversion layer. To find out the angle of attack vs. speed, separate flights were made, as at different angles of attack the speed had to be maintained for no more than 10 seconds running. Each test variant was repeated two or three times. The obtained results were adjusted according to the air pressure and temperature.

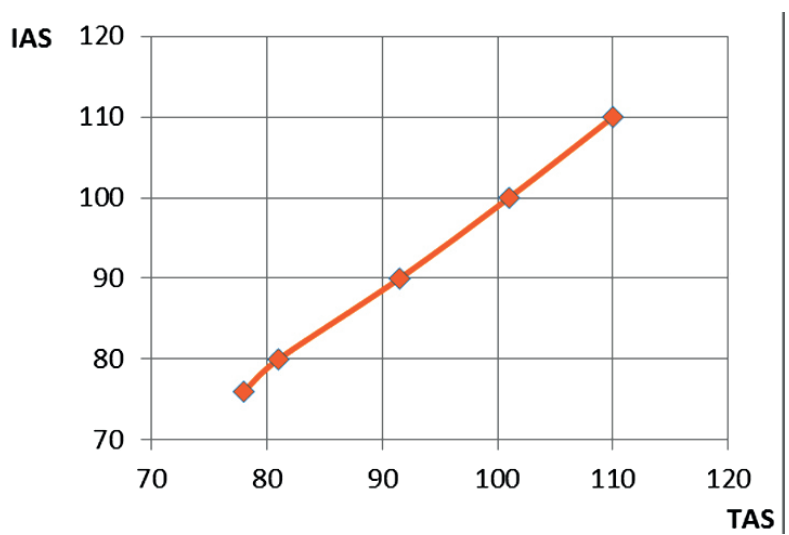

Fig. 11. IAS and TAS values obtained from the calibrating flights

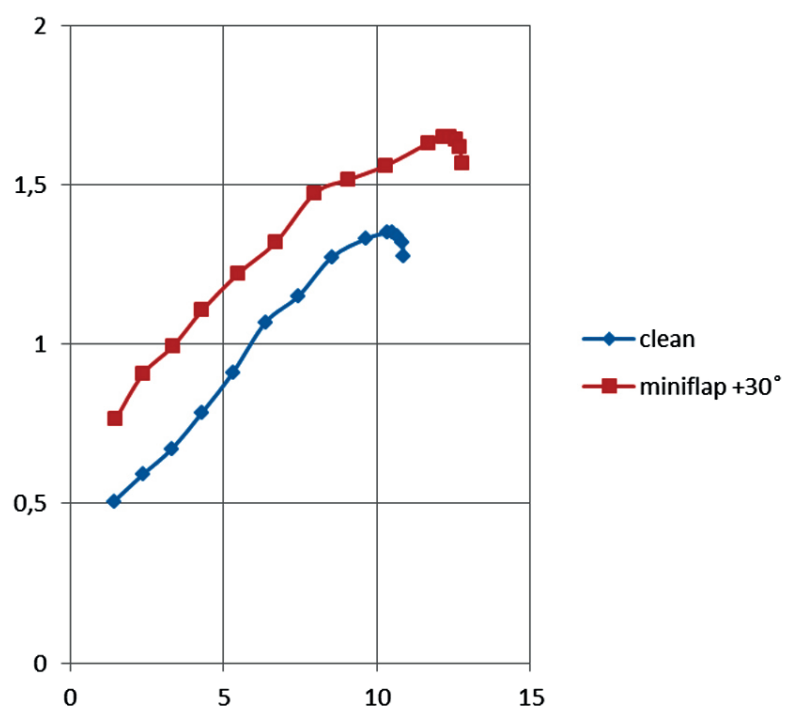

Fig. 12. Sailplane SZD-48-3 Jantar-Standard 3 ES-1004 No: B-1454 lift coefficient $\mathrm{Cl}$ dependence on the angle of attack $a$ without a miniflap and with $\mathrm{a}+30^{\circ}$ deflection angle $2 \%$ chord length miniflap

\section{Results}

With miniflaps of $2 \%$ of the wing relative chord at a $30^{\circ}$ deflection angle, the sailplane's stall speed decreased from 75 to $66 \mathrm{~km} / \mathrm{h}$ and, computationally, the $\mathrm{Cl} \max$ from 1.35 rose to 1.66 (Fig. 12), also taking into account the small growth of the wing area. In addition to this increase, the wing critical angle of attack grew to $1.6^{\circ}$.

The increase of the critical angle of attack when using a Gurney flap has been noted by several authors (Cavanaugh et al. 2007). Usually, it does not exceed $1^{\circ}$, but in one study the critical angle of attack increased to $2.1^{\circ}$ (Vlasov et al. 2007). The analysis of the results obtained by comparing the test flights indicates that the use of miniflaps with lift coefficients $\mathrm{Cl} 0.99-1.21$ and 1.321.66 decreases the drag of the sailplane in comparison with a normal configuration (Fig. 13).

The decrease of the drag need not be caused solely by the drop of the profile drag, it may also be connected 


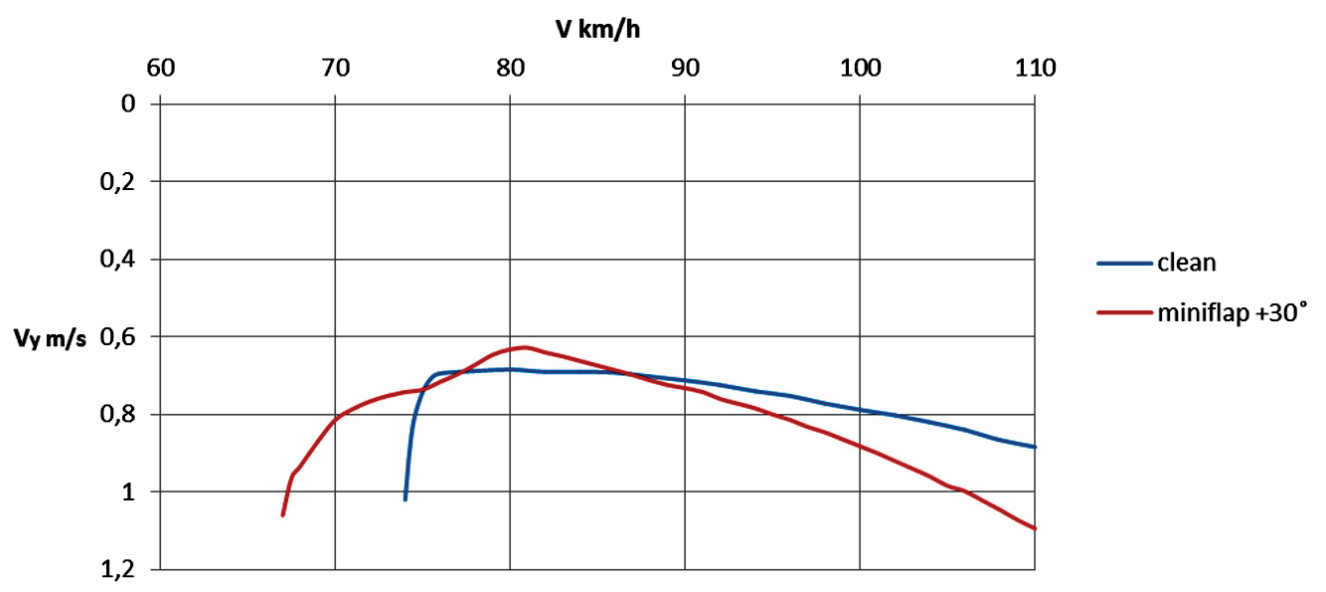

Fig. 13. Influence of a miniflap of a $2 \% \mathrm{C}$ (deflection angle $+30^{\circ}$ ) on the sailplane Jantar-Standard 3 performance (G/S $35.78 \mathrm{~kg} / \mathrm{m}^{2}$ )

to the decrease of the body drag and the interference drag, as the angle of attack decreased to $2.5^{\circ}$ at the same speed. At the airspeed of $81 \mathrm{~km} / \mathrm{h}(\mathrm{Cl} \mathrm{1.13)}$ an anomalous decrease in the sink speed up to $0.63 \mathrm{~m} / \mathrm{s}$ and an increase in the aerodynamic value at the same speed occurred. The most probable cause for the drag decrease is the thinning of the near trailing edge boundary layer as a result of the vortex appearing on the wing surface behind the miniflap. At airspeeds under $70 \mathrm{~km} / \mathrm{h}$ the sink speed increased mainly due to the induced drag, which, in its turn, was generated by the relatively small aspect ratio of the wing (20.2) for gliders. At the same time, at airspeeds over 86 $\mathrm{km} / \mathrm{h}(\mathrm{Cl} 0.99)$, the miniflap increased the sailplane's drag. At a further increase of the speed up to $150 \mathrm{~km} / \mathrm{h}$, apart from the drag, the loads on the ailerons increased as well. According to the test pilot, these loads exceeded the normal flight forces more than twice. During towing, the necessary airspeed for flight decreased typically for this type from $125-130 \mathrm{~km} / \mathrm{h}$ to $115-120 \mathrm{~km} / \mathrm{h}$. At critical angles of attack, the sailplane roll stability and controllability were retained. During one of the test flights, the test pilot managed to keep the plane at a critical angle of attack for a ca of 10 seconds. The controllability was retained, but the vibration, accompanying stall, increased, as the T-stabilizer was also located in the vortice area. To investigate the sailplane's practical behaviour in thermals, a separate flight was made with the purpose of finding out the changes in the controllability and stability generated by the use of miniflaps. The weather was windy and turbulent. The day was characterized by narrow and intermittent thermals. In spite of the turbulence, the sailplane's controllability and stability were good and did not differ significantly from the normal configuration. It was possible to retain the airspeed of $76 \mathrm{~km} / \mathrm{h}$ at a $35^{\circ}-40^{\circ}$ bank angle in a spiral flight, which is significantly lower than the normal airspeed (85$90 \mathrm{~km} / \mathrm{h}$ ) for this plane type at the given regime.

\section{Conclusions}

Similarly to modelling in the programme XFLR 5, the flight characteristics of the sailplane Jantar-Standard 3 improved significantly - $\mathrm{Cl}>1.0$ - when a $2 \%$ chord length miniflap at a $30^{\circ}$ deflection angle was added. $\mathrm{Cl}$ max increased from 1.35 to 1.66 . The critical angle of attack rose from $9.6^{\circ}$ to $11.2^{\circ}$ and the $\mathrm{L} / \mathrm{D}$ value of the sailplane improved to $\mathrm{Cl}>1.0$, especially in $\mathrm{Cl} 1.08-1.19$.

\section{Future work}

In future research, it would be necessary to test the miniflap at a $45^{\circ}$ deflection angle and to find out the accompanying flight parameters. It would be most interesting and necessary to test miniflaps together with the plain flap. The results were promising when considering the modelling in the XFoil programme. Further testing is necessary for the wedge flap. The drag of the tested $2 \%$ c wedge flap at a $45^{\circ}$ angle with a $\mathrm{Cl}$ of 1.0 was approximately $10 \%$ lower than with a miniflap at a $45^{\circ}$ deflection angle (Fig. 14) (Bloy et al. 1997).

With $\mathrm{Cl}$ values in the range of $0.52-0.8$, it would be a challenge to test the miniflap variant with a TE Wedge of $0.8 \%-2 \%$, with which it was possible to decrease the $\mathrm{Cd}$ of an airfoil S904 by Re $10^{6}$ more than 1.5 times (Fig. 7) (Bruscoli 2011). The airfoil S 904 of a 2\% height Gf was tested - it might be studied for wing tips and also for UAV-s. With a serrated Gf Re $0.4 \times 10^{6}$ at a $\mathrm{Cl}$ of 0.71 , the drag decreased to 0.00507 which is nearly twice lower than under usual conditions (Jarzabek 2011).

\section{Acknowledgements}

The authors would like to express their gratitude to Igor Penkov, PhD from Tallinn University of Technology for his valuable advice and the Head of Ridali Flying Club, Einar Viin, pilot, Jaan Susi, and glider pilots, Matti Sillajõe and Alar Õun, for carrying out the test flights. 



Fig. 14. The influence of various types of miniflaps on the airfoil's L/D value (Bloy et al. 1997)

\section{References}

Akademische Fliegergruppe an der Universität Karlsruhe e.V. Jahresberisht 2005-2006 (in German) [online], [cited 15 May 2014]. Available from Internet: http://www.akaflieg.uni-karlsruhe.de/wp-content/uploads/2015/03/2005-2006.pdf

Balagura, J. 2013. Miniklappide aerodünaamilise mõju modelleerimine õhusõidukile Jantar-Standard 3: Lõputöö, Eesti Lennuakadeemia (in Estonian).

Bechert, D. W.; Meyer, R.; Hage, W. 2001. Drag reduction of Gurney flaps and divergent trailing edges [online], [cited 30 May 2014]. Available from Internet: http://www.dlr.de/at/ Portaldata/2/Resources/dokumente/at/AIAA2000_2315. pdf

Bloy, A. W.; Durrant, M. T. 1995. Aerodynamic characteristics of an aerofoil with small trailing edge flaps, Wind Engineering 19(3): 167-172.

Bloy, A. W.; Tsioumanis, N.; Mellor, N. T. 1997. Enhanced aerofoil performance using small trailing-edge flaps, Journal of Aircraft 34(4): 569-571. http://dx.doi.org/10.2514/2.2210

Bruscoli, S. 2011. Airfoil optimization for a solar powered aircraft [online], [cited 15 May 2014]. Available from Internet: http://oatd.org/oatd/record?record=oai\%5C\%3Aetd.adm. unipi.it\%5C\%3Aetd-05212011-180923

Cavanaugh, M. A.; Robertson, P.; Mason, W. H. 2007. Wind tunnel test of Gurney flaps and T-strips on an NACA 23012 wing, AIAA (American Institute of Aeronautics and Astro- nautics) Paper 2007-4175 [online], [cited 30 May 2014]. Available from Internet: http://www.dept.aoe.vt.edu/ mason/Mason_f/AIAA2007-4175.pdf

van Damm, C. P.; Chow, R.; Zayas, J. R.; Berg. D. E. 2007 Computational investigations of small deploying tabs and flaps for aerodynamic load control, Journal of Physics: Conference Series 75. http://dx.doi.org/10.1088/1742-6596/75/1/012027

Drela, M. 1989. XFOIL: an analysis and design system for low Reynolds number airfoils, Low Reynolds Number Aerodynamics, Lecture Notes in Engineering 54. New York: Springer Verlag, 1-12. http://dx.doi.org/10.1007/978-3-642-84010-4_1

Gardner, A. D.; Nitzsche, J.; Neumann, J., et al. 2006. Adaptive load redistribution using mini-TEDs, in $25^{\text {th }}$ Congress of the International Council of the Aeronautical Sciences (ICAS), 3-8 September 2006, Hamburg, Germany [online], [cited 18 May 2014]. Available from Internet: http://icas.org/ ICAS_ARCHIVE/ICAS2006/PAPERS/216.PDF

Hendrix, J. 2011. Measuring glider performance with a flight data recorder [online], [cited 12 April 2011]. Available from Internet: http://www.deturbulator.com/measuringgliderperformance.pdf

Jang, S. C.; Ross, J. C.; Cummings, R. M. 1998. Numerical investigation of an airfoil with a Gurney flap, Aircraft Design 1( 2): $75-88$.

Jarzabek, A. 2011. Low speed wind tunnel testing of aerofoil family for solar powered aircraft: Master's thesis. Imperial College London, UK [online], [cited 24 May 2014]. Available from Internet: http://oa.upm.es/7428/1/PFC_Artur_Jarzabek.pdf

Johnson, R. H. 1989. Sailplane performance flight test methods, Soaring Magazine 07.

Kubrynski, K. 2006. Aerodynamic design and cross-country flight performance analysis of Diana-2 sailplane, Technical Soaring 30(3): 79-88 [online], [cited 22 May 2014]. Available from Internet: http://www.dianasailplanes.com/Tech_Soar_KK.pdf

Liebeck, R. 1978. Design of subsonic airfoil for high lift, Journal of Aircraft 15(9): 547-561. http://dx.doi.org/10.2514/3.58406

Richter, K. 2010. Untersuchungen zur Aerodynamik von Miniature Trailing-Edge Devices in transsonischen Strömungen, DLR Deutches Zentrum fur Luft-und Raumfahrt e.V. Forschungsberichte 09/2010 [online], [cited 20 May 2014]. Available from Internet: http://elib.dlr.de/65260/ (in German).

Vlasov, V.; Kogan, M.; Nalivaiko, A. 2007. Investigation of the control of the flow around a wing using mini-flaps, Fluid Dynamics 43(6): 960-967. http://dx.doi.org/10.1134/S0015462808060173

Wang, J. J.; Li, Y. C.; Choi, K. S. 2008. Gurney flap-lift enhancement, mechanisms and applications, Progress in Aerospace Sciences 44(1): 22-47. http://dx.doi.org/10.1016/j.paerosci.2007.10.001

Wilsey, C. 2012. Continuous lower energy, emissions and noise (CLEEN) technologies development. Boeing program update [online], [cited 28 May 2014]. Available from Internet: https://www.faa.gov/about/office_org/headquarters_offices/ apl/research/aircraft_technology/cleen/2011_consortium/ media/Boeing_CLEEN_Projects_Briefing.pdf 